\title{
To Cover the Many Sins of Galamsey Mining ${ }^{1}$
}

\section{Ernst M. Conradie ${ }^{2}$}

\begin{abstract}
This contribution calls attention to the environmental impact of mining in general and of galamsey mining in Ghana in particular as a theme for theological (and not merely ethical or pastoral) reflection. This topic is approached by placing it in juxtaposition with Christian discourse on sin, understood as a form of social diagnostics. By recovering the category of sin, this contribution seeks uncover the many sins of galamsey mining in the hope that such a prophetic critique will expose any ideological or idolatrous "cover-ups" but will nevertheless be "covered" by the gospel of the forgiveness of $\sin$ (see James 5:19-20).

Keywords Ecotheology, Forgiveness, Gold, Mining, Prosperity gospel, Sin, Social diagnostics
\end{abstract}

\section{Introduction}

Christian ecotheology may be regarded as a twofold critique, namely a Christian critique of environmental destruction and an ecological critique of Christianity (which is structurally similar to the Christian critique of patriarchy and a feminist critique of Christianity in feminist theology). ${ }^{3}$ There are voices within the field that allow one of these two critiques to dominate - so that ecotheology either becomes purely apologetic or reduced to and eventually replaced by discourse on religion and ecology. The genius of ecotheology may well lie in its ability to maintain a creative tension between such a twofold critique. That can best be done if the constructive role of ecotheology is maintained, i.e. by ensuring that the message of the Christian gospel creatively addresses such twofold challenges. This would require an interplay between the pain of the cross and the joy of resurrection hope.

1 This contribution is based on a public lecture delivered at a conference on "The Ecclesiological Approach to Curbing Galamsey in Ghana", hosted by the Ghana Baptist University College, Kumasi, 23 November 2017.

2 Ernst M. Conradie is Senior Professor in the Department of Religion and Theology at the University of the Western Cape where he teaches systematic theology and ethics. He can be contacted at econradie@uwc.ac.za. His most recent monographs are The Earth in God's Economy: Creation, Salvation and Consummation in Ecological Perspective (LIT Verlag, 2015) and Redeeming Sin? Social Diagnostics amid Ecological Destruction (Lexington Books, 2017).

3 I have defended such an understanding of Christian ecotheology in several earlier publications. See e.g. Conradie (2014). 
Although there is by now a huge corpus of diverging literature in the field of ecotheology from around the world, there has been very little ethical and almost no theological reflection on the mining industry within the context of Christian ecotheology. ${ }^{4}$ This is rather surprising as the destructive environmental impact of mining is well-known. Mining, alongside commercial agriculture and industry, are arguably the most destructive spheres of the economy.

In this contribution I hope to call attention to mining in general and to galamsey mining in Ghana in particular as a theme for theological (and not merely ethical or pastoral) reflection. I will approach this topic by placing it in juxtaposition with Christian discourse on sin. Although there are obvious dangers of superficiality here, this strategy is expedient given my current research project entitled "Redeeming Sin? Ecology, Hamartiology and Social Diagnostics". ${ }^{5}$ By recovering Christian discourse on sin I will seek to uncover the many sins of galamsey mining in the hope that such a prophetic critique will expose any ideological or idolatrous "cover-ups" but will nevertheless be "covered" by the gospel of the forgiveness of $\sin$ (see Ps. 32:1-2, James 5:19-20, 1 Peter 4:8) and, on that basis, liberation from the power of $\sin$.

4 In my quite sizable personal collection of around 300-400 books, editions of journals and edited volumes in the field of ecotheology I found no book, essay or chapter that focuses on the mining industry, except for the thesis by Dalton (2015) on coal seam gas from within the Australian context. What I found is a chapter by Kainulainen (2011), a section of 9 pages on mineral resources in Wilkinson (1991:94-103), a sub-section of scarcely more than one page in Borrong (2005:6-7), a page in Conradie \& Field (2000:21-22), and a few paragraphs in Nash (1991:24f, 26f). This is surprising because many other environmental concerns such as agriculture, animal suffering, architecture, biodiversity, biotechnology, climate change, deforestation, energy resources (partially related to mining), food, the industrialised economy, nuclear energy, population growth, poverty, sexuality, technology, trade, transport, waste management, and so forth receive ample attention (see Conradie 2006). I did find additional internet based resources, albeit that these are not necessarily situated in discourse on ecotheology. A search on "mining" in the database of the American Theological Library Association included 191 sources. Of these many used "mining" only metaphorically, 45 focused on the archaeology of ancient sites, 18 on church history, 44 offered prophetic, ethical or pastoral reflections on the mining industry but appeared in popular church-based magazines such as Christian Century (10), Christianity in Crisis (2), Church and Society (5) Sojourners (12), Engage/Social Action (4) and One World (1). Eight articles appeared in academic journals well before 1980. A few others are indeed useful and are cited in this contribution, but less than a handful focus on mining in the African context and then mainly on ministry to mine workers. One has to wonder whether there is not a bias in the global North in this regard since mineral extraction often takes place in the context of colonisation, or in countries of the north several decades ago (albeit not in Canada or the rural USA). There is of course a significant corpus of literature on energy, not so much on coal mining (see Clark \& Lloyd 1974) and a rapidly expanding corpus of publications on hydraulic fracturing (see Cilliers 2017, Connor 2013, Sekhejane 2017, Tucker \& Van Tonder 2015).

5 This is a collaborative project registered at the University of the Western Cape involving some postgraduate students and an annual colloquium on "Redeeming Sin". See also Conradie (2017) 


\section{To mine or not to mine: Is that the question?}

The "many sins" associated with mining are well-known. There is no need here for a detailed account of the destructive impact of mining. Likewise, there have been ample accounts in the media and in scientific reports on galamsey mining in Ghana (a local Ghanaian term for illegal small-scale gold mining, done in numerous sites through shallow digging by hand or light machinery). It may nevertheless help to list some of the concerns that organisations in civil society, including churches, have raised with regard to mining in general and gold mining in particular:

- Gold mining is synonymous with economic inequality given the concentration of wealth in the hands of few and the capitalist exploitation associated with that.

- While the economic value of mining iron ore or coal can readily be demonstrated, it is not clear what benefits to core human needs can be derived from gold mining. Gold mining is aimed at luxury goods such as jewellery or at market stability - which are hardly basic human needs.

- Gold mining have had a negative impact on the health of workers given mining accidents, exposure to toxins, and the hardships of working deep underground.

- Gold mining has led to the contamination of precious surface water by "uncovering" minerals that have never been in contact with air or water to oxidize. Subsequently, to control water run-off from extracted ore poses a long-term problem, best illustrated by the challenges associated with acid mine drainage in mines now closed.

- In many cases extractive mining has destroyed the fertility of soils by uprooting indigenous vegetation while rehabilitation is never fully restorative and all too often neglected. ${ }^{6}$

- Mining is almost always done on the basis of short to medium term planning. Funds allocated for rehabilitation (where this is done under law) seldom have a vista beyond 20 or 50 years while the destructive ecological impact of mining may last much longer.

- Gold mining has all too often brought out the worst in humans given the feverish desire to gain instant wealth.

- Mining has had a destructive impact on family life, especially given the need for migrant labour and the distant location of mines from the homes of workers. This is associated with divorce, juvenile delinquency, extra-marital relationships, prostitution, the spread of venereal diseases and of the HI-virus. This poses serious challenges, not least for Christian ministry in such contexts. ${ }^{7}$

See the study by Witt (2011), Thompson (2017).

7 There are many such stories about ministry in the context of ecclesial histories. For one pertinent 
Given this list that captures something of the destructive impact of mining, Christians may be inclined to denounce all forms of mining as sinful. I leave aside for the moment questions about how the category of "sin" should best be understood and draw on the minimalist secular notion of sin as wrongdoing. It may well be true that all mining is polluted by human sin but then trivially so: the "pervasive perversity" of sin suggests that everything in life has been contaminated by sin so that this does not apply to mining only, although (gold) mining may well serve as an appropriate symbol for the destructive impact of sin.

The question may, instead, be raised whether mine work may be regarded in itself, almost by definition, as something sinful. This may apply to occupations such as assassins and drug trafficking (and not necessarily for prostitution), but few would go so far as to say that mining itself is sinful. Given the economic benefits that human civilizations since antiquity, also throughout the African continent, have derived from mining, many would suggest that there is only one thing that is worse than mining and that would be not mining at all. If so, the problems related to mining concern the methods of mining, financing mining or the applications of the ore. The ore that is mined may be used towards diverse ends, including destructive weapons, for roads and other infrastructure, for subsistence agriculture and for medical purposes. Given such observations it may be necessary to engage in an indepth diagnosis of the problem in order to discern what is at stake here.

\section{Mining the depths of the predicament}

What are the root causes of the many problems associated with mining, gold mining and galamsey mining in particular? To frame the question in this way is to recognise the need to distinguish between the surface-level symptoms of a problem and the deeper, underlying structural causes of such problems. This requires an exercise in what is called root cause analysis. ${ }^{9}$ Most analysts would agree that the triplet of "poverty, unemployment and inequality" capture the symptoms of contemporary challenges in South Africa (although many would nowadays add the impact of state capture). Seeing such symptoms is not hard but identifying their root causes is far from obvious. There would be diverging analyses on what the root causes of unemployment are. An adequate diagnosis would require reflection on such root causes in order to prescribe a remedy that would not remain superficial. If the many sins of (galamsey) mining are to be "covered" by the forgiveness of sin, such sins would first need to be "uncovered" by confession (see James 5:16 in relation to 5:20).

example on migrant labour in South Africa, see the contribution by Maloka (1997).

8 See Rasmussen (2013:100).

9 For a discussion of root cause analysis, see Conradie (2016). 
At the same time it would not do to diagnose the deepest sources of the problem without properly examining the patient. ${ }^{10}$ This is a temptation for Christian prophetic discourse as one can easily assume that the sins of pride, greed and selfishness lie at the heart of the problem, without unpacking the many layers between that and the surface level symptoms. Alternatively, Christians may merely concur with secular analysts on the symptoms without contributing much to the diagnosis. Or Christians may not to be concerned about the causes because they believe they have the appropriate "remedy" of the gospel - which may be tantamount to prescribing inappropriate "medicine".

Let me begin then by commenting on the surface-level symptoms of the problem. One intriguing observation is that the ethical issues associated with (gold) mining are highly diverse and context-dependent. If the symptoms are not the same, one may well wonder whether the underlying causes may not be different too. I will again merely list some of these surface-level concerns that have prompted ethical debate related to (gold) mining and subsequently pastoral concerns. It may be helpful to see how such concerns shift in different phases of mining operations: ${ }^{11}$

- Often debates on mining operations that are still in the prospecting phase focus on environmental impact, e.g. with regard to issues of biodiversity, loss of habitat, rehabilitation of fauna and flora, air pollution, water pollution, and so forth. Such concerns have to be addressed through policy making that takes a wide range of considerations into account and requires active citizen participation. ${ }^{12}$ The vehement debate on hydraulic fracturing in South Africa is a case in point.

- A related debate is on the impact of mining operations on indigenous communities, their cultural and value systems and their means of livelihood. ${ }^{13}$ In the case of galamsey mining communities have to weigh up in the influx of capital

10 See Conradie (2017), chapter 1.

${ }^{11}$ See also the excellent contribution by Knox (2015). He employs the "Five Capitals" model to assess, against the background of Catholic social teaching, the sustainability of the mining industry, i.e. in terms of natural capital, human capital (with respect to health care and human development), social capital, manufactured capital and financial capital. He discusses the impact of the extraction of materials, of manufactured products and the integrity of ecological systems, e.g. in terms of biodiversity. He concludes, quite simply, that "mining in South Africa cannot be considered to be sustainable" (2015:125).

12 For one example, see Anderson (1982).

${ }^{13}$ See the article by Hardenberg (2016) on Odisha in India. He argues that "Politicians and mining companies, as well as their national and international opponents, separate and even oppose the social and the cosmic fields on the basis of conflicting values. In contrast, it is argued that for the local people named Dongria Kond, the mining companies endanger a cultural system of exchange and provisioning that maintains an undifferentiated socio-cosmic field based on the value of life-giving "wealth'." 
against the destruction of arable land, the contamination of water resources and the vulnerability of people to drowning in uncovered diggings that become filled with water.

- In the construction and early phases of mining operations ethical debates often focus on health and safety standards, dangerous working conditions, and the role of risk taking. The horrific circumstances within which mine workers often live and work (and the manifold forms of suffering that entail) is typically the dominant concern related to mining amongst social justice activists. ${ }^{14}$ Often, such working conditions are directly related to the environmental impact of mining operations (especially strip mining) and waste disposal, with specific reference to the contamination of water supplies through the release of toxins, acids and radioactive waste. These problems tend to be addressed as the procedures and infrastructure become better established and as mining companies are held accountable for such working conditions, albeit sometimes only after decades (e.g. in the case of asbestos mining).

- In many well established mines the dominant concern shifts to relationships between mining companies and trade unions, between employers and employees, mostly about wage negotiations, contracts, retrenchment, working conditions and various benefits, including health care, pension and education. In the long run large companies are more or less forced to address such concerns..$^{15}$ In South Africa this is the dominant current focus of ethical discourse on mining.

- Given the location of mines and the use for migrant labour, there are also concerns over the plight of mine workers in terms of family relationships, the need for and the impact of the cultural and religious adaptations that they need

${ }^{14}$ A few references to the available recent literature from around the world may suffice, but there should be many more texts from the early history of the industrial revolution in Europe. See, e.g., Clark \& Lloyd (1974), Corporate Information Center Brief (1973), Jolly (2013), Knox (2015), López \& Ellison (2005).

15 In South Africa such concerns are dominant in the work of the Bench Marks Foundation, a non-profit, research-based faith-based organisation owned by several churches in South Africa. It does advocacy work in the area of corporate social responsibility (CSR) and monitors corporate performance against an international measuring instrument, the Principles for Global Corporate Responsibility. The recent headlines at its homepage are indicative of the kind of concerns raised: "Bench Marks dismisses DRDGold criticism as fatuous" (05/09/2017); "Acid mine drainage real threat to mine-impacted communities" (29/08/2017); "Call for compensation into asbestos in Soweto" (29/08/2017); "British shareholders castigated for taking gold's profit" (29/08/2017); "Largest concentration of uranium on planet threatens Joburg" (29/08/2017); "Gauteng sitting on radioactive time bomb" (29/08/2017); "Radioactive sand being used in housing" (29/08/2017); "Respiratory ailments associated with living close to mine dumps" (29/08/2017); "Building houses in exclusion zones courts disaster" (29/08/2017); “Policy Gap 12: 'Waiting to inhale': A survey of Household Health in Four Mine Affected Communities" (23/08/2017). See http://www.bench-marks.org.za/ (accessed 27 October 2017). 
to make and, in Christian circles, over the demands of ministry to such mine workers. ${ }^{16}$ The demands of labour in mines play an obvious role here, but the main concern is over cultural adaptation.

- In most active mines the mere existence of such mines attract family members of mine workers and unemployed people to the area with the hope of finding some form of employment either within the mines or on the fringes where there is some economic activity. Such rapid growth of local population prompts numerous issues around welfare, housing, health, education, sanitation, other municipal services and so forth that are not directly related to the mining operations. Often churches step in to address such

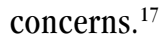

- In the case of decommissioned mines the major concerns are over proper rehabilitation of such mining areas and guarding over issues related to acid mine drainage. $^{18}$

- There are, also in the case of decommissioned mines, considerable debates over illegal mining since former mineworkers scavenge such mines for material from which they can still make a living. Such "zama zama" mining activities go underground in the double sense of the word but then also attract criminality, illicit trading, drug trafficking and trading in contraband. Some would look for ways of formalizing and regulating such illegal mining in order to address concerns over unemployment. ${ }^{19}$

If these are the dominant ethical concerns associated with mining, how may the root causes of such problems be identified? What is the underlying problem? To dis-

${ }_{16}$ See again Maloka (1997), also Leatt (1982). Leatt's sociological study suggests that "In the context of the gold mining industry in SA, religion (Christian and/or traditional African) plays a significant role in assisting the black migrant mineworker to adapt to his new environment as well as to resist total assimilation into the "culture of the mine'" (1982:61).

17 One pertinent example of such ministry is that of Kevin Dowling, the Catholic bishop of Rustenburg, in the heart of the platinum belt in South Africa. He is rightly described as the "voice of the voiceless", concerned with those who are "most vulnerable, especially migrant and refugee women and single mothers, AIDS orphans and child-headed households as well as hurting families." See https://www. americamagazine.org/content/dispatches/bishop-kevin-dowling-south-africas-voice-voiceless (accessed 27 October 2017).

${ }^{18}$ The Bench Marks Foundation expresses deep concerns in this regard: "AMD is produced during the mining process when large quantities of rock containing sulphide minerals are excavated from an open pit or exposed in an underground mine, and react with water and oxygen to create sulphuric acid. The acid will leach from the rock until the sulphides and pyrites are leached out, a process that can last thousands of years. The acid is carried off the mine site by rainwater or surface draining and deposited into nearby streams, rivers, lakes and groundwater." See again the headline "Acid mine drainage real threat to mine-impacted communities" under http://www.bench-marks.org.za/ (accessed 27 0ctober 2017).

${ }^{19}$ For one theological contribution in this regard, see Landman (2015). 
cern that, one would clearly need to mine deeper. This is a very hard and complex question to answer. I cannot do more here than to point to a few layers.

Firstly, some would suggest that the problems are mainly of a technological level. This would account for mining accidents, health concerns and water pollution. The damage caused by galamsey mining with regard to the pollution of river systems can be limited if gold is not extracted from the ore by using arsenic or mercury or at least by containing such uses.

Secondly, some would suggest that the problem is one of inadequate business planning and management. Surely, many problems can be resolved by well-structured and well-regulated operations, long-term planning and financial provisions for rehabilitating decommissioned mines?

Thirdly, one may also argue that the underlying problem is mainly of an economic nature. On the one hand one may say that poverty, unemployment and inequality drive those without any means of sustaining a livelihood to opt for illegal mining in hazardous circumstances. It is the economy that is failing them. On the other hand one may argue that gold mining always tends towards the concentration of wealth and the means of production in the hands of a few entrepreneurs who seek to monopolise the industry in their own financial interests. In highly industrialised countries such financial interests shift towards shareholders and investment managers. For others, the problem lies in the utilitarian logic employed in economic discourse that focus on economic contributions to the common good (understood mainly as the production of wealth measured by GDP) and is willing to sacrifice those on the margins for the sake of overall well-being. ${ }^{20}$

Fourthly, others would insist that such economic structures are supported by cultural trends. More specifically, the now global culture of consumerism, found amongst the affluent and the lower-middle class (and the poor) alike, stimulates the relentless production of wealth which has such a destructive ecological impact in the sectors of mining, industry and commercial agriculture, not to mention fishing and forestry. In the case of jewellery (gold and diamonds), but also cars, housing and clothing, this is exacerbated by “conspicuous consumption", i.e. consumption aimed at gaining cultural prestige.

Fifthly, beneath such cultural factors one may also point to moral influences. One may offer a long list of vices associated with gold mining but also in the underlying culture that invites (or enforces?) such mining activities. Seen in this way, galamsey mining is merely a symptom of an underlying disease in which whole societies have become entrapped. It may be the worst and most visible manifestation, but it would be inappropriate to put the blame on the miners or even the contractors only. It is a whole culture that has gone wrong.

${ }^{20}$ See Jolly (2013:229-230), with reference to Pope John Paul II. 
Finally, one may also identify spiritual factors ${ }^{21}$ Moral discernment is needed in cases where it seems far from obvious what the best strategy would be to act responsibly. This prompts ethical debates and the need for ethical theories to reflect on the basis for making any moral judgments. However, there are also cases where it is quite evident what is right, where we have the means to do what is right but still find ourselves unable to do so. It then becomes apparent that we lack the moral vision, moral energy and leadership to act accordingly. A few examples will suffice: Christians know that they need to love their neighbours as Christ has loved them, but often find themselves unable to do so. This suggests a spiritual rather than a moral problem. Executives in companies may become tempted to accept bribes and lucrative deals that are illegal and unjust to other companies. To accept such a bribe is indeed wrong but there is strictly speaking not a problem here that requires moral deliberation; there is a spiritual problem located in the inability to do what is right. Arguably this applies to climate change too: globally we know what we need to do, we have the technological and financial means to do so, there is political will to do so (i.e. the Paris Accord of 2015), but collectively we still seem unable to ensure that our response is commensurate with the enormous scale of the challenge. ${ }^{22}$

Does this also apply to galamsey mining? This is not obvious (to me). It is easy to denounce such mining activities as destructive but if my analysis above is correct, it would be inappropriate to blame this only on the miners. It is also not clear what alternative livelihoods are available to the mine workers, if not the entrepreneurs extracting the gold from the ore.

\section{Is Galamsey Mining (a) Sin?}

I have argued elsewhere that Christian sin-talk may appropriately be regarded, at least from the outside, as a form of social diagnostics. ${ }^{23}$ It can contribute to interdisciplinary efforts to understand what is wrong with the world. Let me put this thesis to the test: can this be appropriated in the case of galamsey mining? If so, what can Christian discourse on sin contribute to such diagnostics? The contribution may lie in merely participating in and supporting the work of others. However, it would not help much to merely reiterate what others are saying. Is there something distinct that Christian discourse on sin can contribute that others cannot?

${ }^{21}$ As Ecumenical Patriarch Bartholomew I of Constantinople (in WCC 2005:67) observes, "Climate change is much more than an issue of environmental preservation. Insofar as human-induced, it is a profoundly moral and spiritual problem. To persist in the current path of ecological destruction is not only folly. It is no less than suicidal, jeopardizing the diversity of the very earth that we inhabit, enjoy and share." See also Pope Francis' acclaimed encyclical Laudato Si', "Merely technical solutions run the risk of addressing symptoms and not the more serious underlying problems" (par. 144).

22 See again Conradie (2017), 1-22.

23 See Conradie (2017). 
There seems to be a superficial correlation between traditional Christian notions of sin and environmental concerns. One may readily identify secular equivalents for categories such as pride (anthropocentrism), greed (consumerism), sloth (moral failure, a lack of sustainable development), violence / killing (domination in the name of differences of gender, race, class and species), folly (irresponsible policy making), and unbelief, i.e. a broken covenant relationship with God (alienation from the earth as our one and only home) ${ }^{24}$ In the case of galamsey mining one may easily witness the role of consumerist greed, the violent destruction of ecosystems and the failure of efforts towards sustainable development. Does this constitute a Christian contribution to ethical reflection on galamsey mining? Hardly, although one should not underestimate the availability of the moral vocabulary of the Christian tradition in the public sphere, even if the theological connotations attached to such concepts have typically become secularised.

To mine deeper than such superficial correlations, one would need to probe the Christian notion of sin. What kind of thing is sin? The answer is, of course, that $\sin$ is not something that one can identify and describe but rather the privation of the good. To explore sin may be fraught with many dangers. It is a virtual minefield in which mining deeper may mean to trigger a landmine. In Christian reflection on the nature of sin the same conclusion is reached again and again, namely that sin cannot be defined but can only be opposed. ${ }^{25}$ Any attempt to do so may well underestimate the way in which sin morphs into different manifestations. If it could be captured in a single formula it might have been possible to isolate, contain and surgically remove sin like a cancerous growth. Instead, sin is seen as elusive and hideous, re-emerging in new forms. Consider this list of conflicting interpretations of $\sin :{ }^{26}$

- Sin describes individual acts of human wrongdoing: what individuals do to others, to themselves and to nature around them.

- Sin is not just a matter of doing, but also of thinking and saying. It is about dispositions, attitudes, attachments - which provide the breeding ground for wrongdoing.

\footnotetext{
${ }^{24}$ See Conradie (2016).

${ }^{25}$ See the comment by Bonhoeffer (1997:120) on the related question of the origin of evil: "The question why there is evil is not a theological question, for it presupposes that it is possible to go back behind the existence that is laid upon us as sinners. If we could answer the question why, then we would not be sinners. We would blame something else. So the 'question why' can never be answered except by the statement 'that' which burdens humankind so completely. The theological question is not a question about the origin of evil but one about the actual overcoming of evil on the cross; it seeks the real forgiveness of guilt and the reconciliation of the fallen world."

${ }^{26}$ For a more detailed discussion, see Conradie (2017), chapter 4.
} 
- Sin also refers to what is left undone, a failure to accept responsibility, duties not fulfilled.

- Sin describes the character of a person rather than particular things that a person may do. Being a sinner is way more important than sinning. Habitual sin is much harder to stop.

- Sin describes the quality of a (broken) relationship of trust and loyalty, not the dispositions or deeds of any one individual. If so, one cannot sin on one's own. Sins in the plural are manifestations of broken relationships.

- Such broken relationships are embedded in wider networks of families, clans, institutions and affiliations. Sin becomes manifest in what one party does to another but is best understood as a relationship going awry.

- Sin is best understood as structural violence; it describes systems of oppression such as patriarchy, slavery, colonialism, apartheid, castes, capitalism, ecological destruction, a situation in which individuals and organisations alike are caught up.

- This may be true but then the focus should be on the power of ideological distortions: sin is about classism, sexism, racism, elitism, homophobia, xenophobia, etc.

- Sin cannot be reduced to something moral but is primarily something religious. It is indeed about broken relationships but then a broken relationship with God, broken at least from our side.

- Sin is best understood as idolatry. If it is religious in nature, it is not merely about an individual's relationship with God but about unbelief, rebellion, idolatry, putting one's trust in principalities and powers that cannot save us.

- Sin is about heresy, about radically distorting the Christian gospel to serve one's own interests.

Another, typically reformed, way of reflecting on these notions of sin is in terms of the distinction between sin as guilt and as power. Some would focus on sin as guilt and then attend to things that individuals do. Others would focus on sin as power and then attend to how individuals are influenced by forces beyond their locus of control. We are caught up amidst evil forces that are more powerful than what we can cope with and from which we cannot escape. A one-sided emphasis on either is dangerous. To focus on individual actions is to trivialise sin, to look for particular instantiations of sin as if there are other actions, attitudes, dispositions and thoughts that are not contaminated by sin. To focus on sin as power only is to portray individuals and groups as victims of forces beyond their control for which they therefore ultimately do not need to accept responsibility.

I do think that it is possible to combine an understanding of sin as power and as guilt in order to avoid such excesses. Perhaps one may start with sin as power 
(structural violence). Accordingly sin may be understood as pervasive perversity. It is the mess that we find ourselves in. One may then need to add, firstly, that this is a mess to which we (humans) and our predecessors have all contributed in one way or another to create or to worsen the mess. However, there is no need to argue that we have contributed equally. Consider the role of those in positions of political and economic power but also those patients (infants, the sick, the senile) on whose behalf others act. The victims of history are never completely innocent either and may well become the perpetrators of tomorrow. Secondly, this is a mess that causes suffering to all of us, including other animals and plants, albeit again not equally so. The suffering of the victims may be obvious but tyrants and torturers also suffer the consequences of oppression. However, it would be obscene to equate the suffering of the rapist and the rape victim. Thirdly, Augustinians (more than Pelagians) would add that this is a mess from which we cannot escape, at least not by ourselves. Our best efforts at moral renewal, reconstruction, transformation and social development, remain flawed and often even exacerbate the problem. In short, sin describes the mess that we find ourselves in, to which we all contributed (but not equally so), under which we all suffer (again not equally so) and from we cannot escape.

The Christian message of salvation typically responds to such a mess in three ways, namely through liberation from the power of sin, forgiveness for sin as guilt and moral guidance to address the lasting impact of sin. As I have argued elsewhere (following Gustaf Aulén famous typology), these three ways are often in conflict but may be integrated by focusing on the present impact of sin, the historical roots of sin and the lasting presence of sin that cannot be completely eradicated without making things worse. ${ }^{27}$

How does such an analysis help to illuminate issues around galamsey mining? A few very brief comments may suffice. It should be clear that those workers involved in mining the ore may be regarded both as victims of economic inequality (structural violence) well beyond their control and as perpetrators of ecological destruction (folly). Those responsible for processing the ore (and who make significant profits from the labour of the workers) are guilty of domination in the name of differences especially of class. They may well be guilty of a range of vices. The rest of the Ghanaian population are trapped in the mess given the impact of the contamination of river systems and water supplies and the destruction of arable land.

Do these comments add anything to secular critiques of galamsey mining? That would hardly be the case. One may of course seek to relate the sins of galamsey mining to unbelief, to rebellion against God, to a broken relationship with the triune God. Accordingly, evangelicals may suggest that the solution would be conversion,

27 See Conradie (2010). 
becoming born again, while Pentecostals may hold that only the transformative power of the Holy Spirit will be able to overcome the threats of galamsey mining. Indeed, what is required is then nothing short of exorcism. Others would suggest that nothing short of liberation from the destructive impact of the mining industry is required in order to address poverty, unemployment and inequality (e.g. in South Africa). But few would suggest that we should be liberated from mining itself.

I do not wish to comment on such remedies but the following observation may be pertinent: the more specifically Christian a critique of galamsey mining is, the less helpful it becomes to understand what went wrong with galamsey mining. Inversely, the more detailed the focus is on galamsey mining, the less a particularly and authentically Christian critique would be found. Where does such an impasse leave us? ${ }^{28}$ This is a pertinent question given the title of this contribution, namely the need to both "uncover" such sins through prophetic critique and to "cover" such sins without slipping into a tacit ecclesial legitimation (a cover-up) of such sins.

\section{Mine, Mine, Mine, Jesus is Mine! Ideology, Idolatry and Heresy?}

To focus only on ethical wrongdoing or theological reflection may lead one to inadvertently miss three intermediate aspects, namely the role of ideology, idolatry and heresy. How may these be related to galamsey mining?

Ideology may be understood in the neutral sense of an underlying worldview but it is best to regard this in the pejorative sense of systematic distortions typically operating sub-consciously amongst groups of people in society. The impact of racism, colonialism, capitalism and patriarchy may serve as well-known examples of such ideological distortions as long as one focuses on sets of assumptions that people take for granted, scarcely ever reflect on, while such assumptions still influence behaviour on a daily basis. In the examples above such assumptions would revolve around white supremacy, European standards for civilisation, the freedom of the market to regulate supply and demand, and the presumed authority of fathers in the family. Other examples may be easily multiplied.

There may be several ideologies that influence galamsey mining operations. It would be inappropriate, though, not to recognise the impact of a culture of consumerism. One may say that the lure of gold, flaunting wealth, epitomises consumerist dreams and aspirations even though this remains out of the reach of many but royalty and the elite. Consumerism is not only related to the products of galamsey

${ }^{28}$ Here I would endorse the assessment by Jolly (2013:329) who suggests that "any faithful and effective Christian ethical response [to strip mining in the Appalachians] must be rooted in hope". This clearly responds to the sense of despondency over the destructive impact of such mining operations. He adds that "Christian hope embraces these experiences, working in constant communion with faith and love to transform and reconcile our horrors and, in turn, the world" (2013:329). 
mining (i.e. gold), but also to the economic inequalities that lead people to seek employment in hazardous circumstances and to the vices of folly, injustice and naked greed. Elsewhere I have argued that there are at least six points of entry for a critique of consumerism. All of these may be pertinent to galamsey mining:

- An ecological critique: The consumer society is not sustainable;

- An economic critique: Consumerism exacerbates economic injustices;

- A social and psychological critique: The affluent have become the victims of their own desires;

- A virtue ethics critique: Consumerism undermines virtue and breeds vice;

- A hermeneutical critique: The consumer society encourages commercialized cultural and religious practices; and

- A theological critique: Consumerism amounts to idolatry. ${ }^{29}$

Idolatry may be best understood as that in which we ultimately put our trust. Idolatry operates as a functional replacement for faith in God. It amounts to putting trust in false saviours, in things that are not trustworthy, as distorted or misplaced trust (in education, health, the power of positive thinking, family networks, some political messiah, the market, one's bank balance, etc.). Accordingly, as critics such as Bob Goudzwaard, Harvey Cox and Pope Francis suggest, market-based consumerism may well amount to idolatry. ${ }^{30}$ Does that apply also to practices around galamsey mining? That is hard for any outsider to tell, but this may put the blame, inappropriately, on those mineworkers who feel that they have no other option but to seek a livelihood in this way.

Heresy may be regarded as the conscious or sub-conscious distortion of the gospel, often for personal or collective gain, resulting in the exclusion of others. In theological debates in South Africa in the 1980s apartheid was described, accordingly, not merely as form of injustice, but also as a quasi-soteriology, ${ }^{31}$ as a form of idolatry, as a pernicious ideology, and as a heresy that legitimised racial segregation for the sake of economic and cultural interests. What makes this worse is the theological legitimation, in the name of the gospel of salvation in Jesus Christ through the Spirit, of such interests.

What heresies may be associated with galamsey mining? One would not expect such heresies to be prevalent amongst the mineworkers or the entrepreneurs that profit form that. Instead, one would need to look for such heresies amongst

${ }^{29}$ See my Christianity and a Critique of Consumerism: A Survey of Six Points of Entry (Conradie 2009). In each case I also offered a critique of the critique in order to circumscribe the hinges on which the debate turns.

${ }^{30}$ For a discussion, see Conradie (2009), Chapter 7. See also Cox (2016); Pope Francis (2015), Goudzwaard (1989).

${ }^{31}$ See Coetzee and Conradie (2010). 
churches, perhaps even churches that fiercely denounce galamsey mining. This is not so hard to recognise given ongoing debates in Ghan $\mathrm{a}^{32}$ and elsewhere in Africa on the prosperity gospel, the gospel of "wealth and health" ${ }^{33}$ It is not for me to resolve such debates here but only to point to the danger of hypocrisy, namely to offer prophetic critique against those that seek quick profits through mining, while not seeing that the same temptation may be found in religious attempts to secure divine intervention and, on that basis, more or less instant gratification. This would amount to a cover-up for corruption that can hardly "cover" many sins.

One may also point to other distortions of the gospel, including the possessive individualism that is found in some ways in which Christianity is portrayed in sermons, rituals and popular lyrics. I was naughty to use one such lyric in the title of this section. This was done in jest, only because of the obvious pun, but this is still indicative of the underlying problem. Here are a few examples of such lyrics, widely available from the internet:

Mine mine mine, Jesus is mine

Jesus is my saviour day by day

Mine mine mine, Jesus is mine (unknown origin).

Fade, fade, each earthly joy,

Jesus is mine!

Break every tender tie,

Jesus is mine!

Dark is the wilderness,

Earth has no resting place,

Jesus alone can bless,

Jesus is mine! (Jane C. Bonar, 1843)

Turn your eyes upon Jesus,

Look full in His wonderful face;

And the things of earth will grow strangely dim

In the light of His glory and grace (Helen H. Lemmel, 1922).

32 See, amongst many others, Agana (2015), Gifford (2004) Kahl (2015), Kalu, (2008), Lauterbach (2016), Rey (2015) and the helpful overview by Heuser (2016) that provided such references.

${ }^{33}$ There is a rapidly expanding corpus of publications in this regard. See, for example the excellent overview by Heuser (2016). He recognizes that it is impossible to generalize on the socio-economic impact of the prosperity gospel given urban/rural divides, class differences amongst proponents and excesses. He states that "A township-based ethics of survival is different from an urban and middleclass 'progressive' Pentecostalism; while business management oriented churches have aspirations to transform society, the socio-economic horizon of churches entertaining a strong sacred secrecy around prosperity rather remains short-term and confined to internal dynamics" (2016:8) 


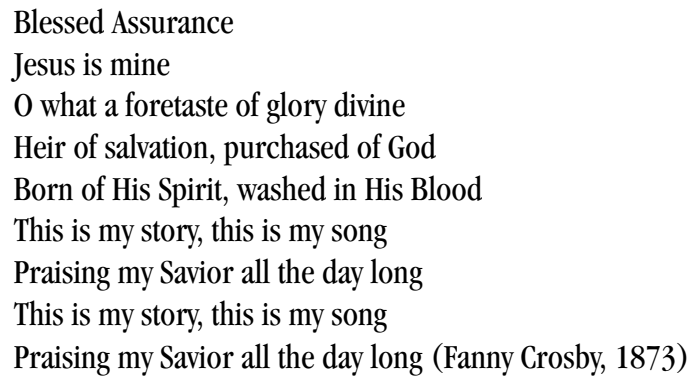

The use of the word "my" in "my Saviour" could focus on the One who saves (Jesus) but can easily degenerate into a possessive appropriation (the one who belongs to me), so that there is little difference between a saviour and a body guard.

\section{Gold standard? On the Value of the Material}

As I observed in the introduction above, Christian ecotheology may be regarded (as a twofold critique, namely a Christian critique of environmental destruction and an ecological critique of Christianity. In this contribution the value of such a twofold critique has been demonstrated with respect to Christian discourse on sin and secular discourse on galamsey mining. There is indeed a need for Christians to collaborate with others in civil society in a critique of the ecological destruction associated with galamsey mining. Christian theology brings along a fairly sophisticated prophetic and pastoral vocabulary that helps to mine the depths of the root causes of such destruction. It may not be necessary to introduce specifically Christian notions of sin as a broken relationship with the triune God in such public discourse, but it would remain appropriate to keep alive such an understanding of sin in the form of arcane disciplines (with reference to Dietrich Bonhoeffer).

At the same time, reflection on galamsey mining has illustrated the need for an ecological critique of Christianity. In particular, Christians and churches may need to be alert to the dangers associated with the prosperity gospel, possessive individualism and, as I argued above, the temptation to undervalue that which is material, bodily and earthly. The problem is not mining gold, but destroying the lives of mine workers, river systems and contaminating water supplies in doing so. That may well provide the gold standard for such a critical assessment.

It would be mistaken, though, to associate the underlying problem with materialism and, by implication, to seek spiritual solutions to ecological destruction. An ecological critique of Christianity is not merely aimed at overvaluing that which is material, but also at undervaluing that. Christianity is sometimes described as the most materialist of all religions. This may well be appropriate. Not only does it 
embrace matter as good, but also proclaims that God entered the world in human flesh. Jesus became flesh, he died for us and was raised to life and ascended in a bodily form. The Spirit hovers over the deep, dwells amongst God's people and lives within our bodies which are called "a temple of the Holy Spirit". The church is described as the body of Christ. The Holy Communion is a form of "reverent consumption" in which the act of consumption is turned inside out: the consumer is consumed; to eat such food means to become part of another body, the body of Christ. The Christian vision of hope is that God will make God's home amongst us, on earth as it may be in heaven. This suggests that that which is financial, material, bodily and earthly may be or become a vehicle of God's presence. When we talk about human bodies and sexuality, money, non-human animals, trees, flowers or stones we stand on holy ground. ${ }^{34}$

Accordingly, the problem with consumerism is actually that it is not materialistic enough! The problem is not our attachment to material possessions but rather a sense of detachment fuelled by the desire for something different. ${ }^{35}$ As Jay McDaniel comments, "If we loved matter more, we wouldn't use it so wastefully. We would take care of old things - like old furniture, old clothes, old shoes, and old homes - and love them." ${ }^{\prime 36}$

A critique of consumerism will become shallow and distorted if it fails to appreciate that which is material, bodily and earthly. The Christian quest for transcendence can only be based on an appreciation for God's immanence in creation, in human culture and in the church as the body of Christ. A vision of God is necessary in order to see the world within perspective, but then the aim should be to see the world through God's eyes. ${ }^{37}$ As Douglas John Hall observes, the symbol of the cross signifies that God regards the world as so good, so beautiful, so precious that it is worth dying for. The cross of Jesus Christ is God's claim to this world, the claim of a lover yearning to love and be loved, not the claim of a despot yearning for power, control and glory. ${ }^{38}$

Does that apply to gold as well? Is gold not the symbol of greed, luxury and a concentration of wealth in the hands of few? The biblical witnesses provide a surprisingly varied array of references to gold. According to one online thesaurus, there are some 189 verses in the Bible that include references to gold while the

${ }^{34}$ For a more detailed discussion, see Conradie (2012).

${ }^{35}$ See Cavanaugh (2008:33f).

${ }^{36}$ See McDaniel (2000:68).

${ }^{37}$ This is the core theme of my reflections on the search for an "earthly spirituality". See Conradie (2005).

${ }^{38}$ See Hall (2003:37). 
word appears no less than 443 times ${ }^{39}$ In the Christian canon the second chapter (Gen. 2) as well as the second last chapter (Rev. 21) contain positive references to gold. The river named Pishon flowed into a land called Havilah, where there were great quantities of high quality gold (Gen. 2:10-14). In the new Jerusalem, "the twelve gates are twelve pearls, each of the gates is a single pearl, and the street of the city is pure gold, transparent as glass" (Rev 21:21). There are no less than seven words for gold in Hebrew (including the most common term zahab, בהז), while


references to gold in the book of Revelations alone.

Most of these cases refer to gold in a more or less neutral sense of the word, i.e. with reference to artistic objects (e.g. jewellery), liturgical objects, gifts, weights, or the equivalent of coinage. In one case gold describes the splendour of God's own coming (Job 37:22). There are other references that are situated in contexts of imperial oppression, e.g. as a way of exacting tribute (1 Kings 20:3) or bounty in war. In some cases gold functions as a symbol of the desire for affluence (Matt. 10:9, James 2:2), a critique of vanity (Eccl. 2:8), an inappropriate trust in what money can buy or a critique of idolatry (Ex. 20:23, 32:1-4, 1 Kings 12:28, Job 31:24-25, Ps. 115:4, Dan. 5:4, Zeph. 1:18) or for a comparative assessment of what is most valuable in life (Job 28:15, Ps. 19:10, Ps 119:127). In a few cases gold as a noble metal also refers to purity and thus functions as a symbol for ritual purification (Zech. 13:9) or testing the faith (Job 23:10, Prov. 3:14, 17:3, Mal. 3:3). This is best evidenced in 1 Peter 1:7: "so that the genuineness of your faith - being more precious than gold that, though perishable, is tested by fire - may be found to result in praise and glory and honour when Jesus Christ is revealed" (NRSV).

It would therefore be inappropriate to focus only on the biblical critique of gathering riches symbolised by gold, even though this is so dominant in the canonical gospels.

\section{Covering Many Sins? The Need for a Constructive Contribution}

Such a twofold critique would remain shallow and hollow without a constructive contribution. Christian ecotheology would need to offer guidance in this regard in order to "cover" the many sins of galamsey mining. In short, a confession of sin would be counter-productive without a recovery of the gospel of the forgiveness of sins and of liberation from the destructive impact of sin (the ecological mess in which we find ourselves). Only on this basis does a prophetic vision of hope become possible (as illustrated with the reference to gold in Revelations 21 and 22).

${ }^{39}$ See https://bible.knowing-jesus.com/topics/Gold (accessed 24 October 2017). This article is quite helpful and complete, if not very scientific in its focus. 
The meaning of the metaphor "cover" in biblical texts such as Psalm 32, James 5:20 and 1 Peter 4:8 is not immediately clear $(\varkappa a \lambda u ́ \pi \tau \omega=$ to cover, while $\dot{a} \pi \circ x a \lambda v^{\prime} \pi \tau \omega$ is to reveal). It can mean to keep hidden behind a veil or a blanket (i.e. to conceal). Along such lines it would help to protect the honour of a person from being shamed and stigmatised. A layer of clothes covers one's nudity. However, this can easily deteriorate into cover-ups for crime and corruption. It can also refer to a protective layer (paint or a table cloth). To cover someone as a body guard is to prevent that person from being harmed or to allow a military operation to proceed under protective gunfire. In contemporary English it can refer to a journalist covering a story, to funding that covers expenses, to animals copulating, to defenders covering an attack in soccer or rugby, or a fielding position in cricket that prevents runs being scored.

What would that mean in the context of galamsey mining though? This is not for me to answer as there would be a range of pastoral situations with role players inside and outside Christian communities. One would need to consider church members involved in galamsey mining at the level of small scale mining but also at the intermediate level of traders in gold and in paving the way for larger companies to extract gold. The church may also profit indirectly from galamsey mining through the offerings of such members. The complicity of the church in preaching a gospel of "many blessings" without recognising the "many sins" should not be underestimated. This may well entice church members to gain wealth quickly and to regard that as God's blessing.

Perhaps the letter of James, so alert to the corruption of riches may be relevant for those who profit directly or indirectly from galamsey mining:

1 Come now, you rich people, weep and wail for the miseries that are coming to you. 2 Your riches have rotted, and your clothes are moth-eaten. 3 Your gold and silver have rusted, and their rust will be evidence against you, and it will eat your flesh like fire. You have laid up treasure[a] for the last days. 4 Listen! The wages of the laborers who mowed your fields, which you kept back by fraud, cry out, and the cries of the harvesters have reached the ears of the Lord of hosts. 5 You have lived on the earth in luxury and in pleasure; you have fattened your hearts in a day of slaughter. 6 You have condemned and murdered the righteous one, who does not resist you (James 5:1-6, NRSV).

This critique is followed by a call for the open confession of sins for the sake of healing including, one may add, the healing of the land and the purification of its waters. In the context of galamsey mining one may perhaps paraphrase the last verse in this way: "My brothers and sisters, if anyone among you wander away from 
the truth [by profiting from galamsey mining] and is brought back by another, you should know that whoever brings back a sinner from wandering will save the sinner's soul from death [and the body from poisoned water] and will cover a multitude of sins (James 5:19-20, NRSV).” This seems to indicate the distinctive task of the church, a task that government and other organisations in civil society can hardly address.

\section{Bibliography}

Agana, Wilfred A., 2015 "Succeed Here and in Eternity": The Prosperity Gospel in Ghana. Frankfurt: Peter Lang.

Anderson, Terence R. 1982. Ethics, Uranium Mining, and Public Participation in Development Decisions. The Annual of the Society of Christian Ethics 2, 99-129.

Bonhoeffer, Dietrich 1997. Creation and Fall: A Theological Exposition of Genesis 1-3. Dietrich Bonhoeffer Works in English, Vol. 3, edited by John W. de Gruchy. Minneapolis: Fortress.

Borrong, Robert 2005. Environmental Ethics and Ecological Theology: Ethics as Integral Part of Ecosphere from an Indonesian Perspective. Ph.D. Dissertation, Vrije Universiteit Amsterdam.

Cavanaugh, William T. 2008. Being consumed: Economics and Christian life. Grand Rapids: WB Eerdmans.

Cilliers, Johan 2017. Fracking in the Karoo? Religious-Aesthetical perspectives on a South African Sustainability Debate. Paper read at the Kosmos summer school on "Religion, Sustainability and Politics", hosted by the Faculty of Theology, Humboldt University in Berlin, 7-10 June 2017.

Clark M. J. \& Lloyd R. B. 1974. Is Strip Mining Obscene? A Case for the Abolition of Strip Mining in Appalachia. Church \& Society, May-June 1974, 44-49

Coetzee, Murray H. \& Conradie, Ernst M. 2010. Apartheid as Quasi-soteriology: The Remaining Lure and Threat. Journal of Theology for Southern Africa 138, 112-123.

Connor, Lena R. 2013. Justified By Faith: The Upper Susquehanna Lutheran Synod and the Pennsylvania Natural Gas Fracking Controversy. Pomona Senior Theses 83. http://scholarship.claremont.edu/pomona_theses/83.

Conradie, Ernst M. \& Field, David N. 2000. A Rainbow over the Land: A South African Guide on the Church and Environmental Justice. Cape Town: Western Cape Provincial Council of Churches.

Conradie, Ernst M. (ed) 2012. Does matter matter? The significance of that which is financial, material, bodily and earthly in theological perspective. Study document posted on the website of the Dutch Reformed Church' Commission for Public Witness. http://ngkerk.org.za/index. asp?bodyType=as_publieke_getuienis.

Conradie, Ernst M. 2006. Christianity and Ecological Theology: Resources for further Research. Study Guides in Religion and Theology 11. Stellenbosch: SUN Press. 
Conradie, Ernst M. 2009. Christianity and a Critique of Consumerism: A Survey of Six Points of Entry. Wellington: Bible Media.

Conradie, Ernst M. 2010. The Salvation of the Earth from Anthropogenic Destruction: In Search of Appropriate Soteriological Concepts in an Age of Ecological Destruction. Worldviews: Global Religions, Culture, Ecology 14: 2-3, 111-140.

Conradie, Ernst M. 2013. Contemporary Challenges to Christian Ecotheology: Some Reflections on the State of the Debate after Five Decades. Journal of Theology for Southern Africa 147, 106-123.

Conradie, Ernst M. 2015. The Earth in God's Economy: Creation, Salvation and Consummation in Ecological Perspective. Studies in Religion and the Environment Vol. 10. Berlin: LIT Verlag.

Conradie, Ernst M. 2016. Penultimate Perspectives on the Root Causes of Environmental Destruction in Africa". Scriptura 115, 1-19. doi:http://dx.doi.org/10.7833/115-0-1279 .

Conradie, Ernst M. 2017. Redeeming Sin? Social Diagnostics amid Ecological Destruction. Lanham: Lexington Books.

Corporate Information Center Brief 1973. The Western Coal Rush: Power, Profits, and Pollution. Church \& Society, May 1973, 25-30.

Cox, Harvey 2016. The Market as God. Cambridge: Harvard University Press.

Dalton, Christopher 2015. How an Australian Theology of Land Can Inform the Public Debate Surrounding the Coal Seam Gas Industry. D.Phil. thesis. School of Religious Studies, Charles Sturt University.

Francis (Pope), 2015. Laudato Si: On Care for Our Common Home (Encyclical Letter). Vatican City: Liberia Editrice Vaticana.

Gifford, Paul 2004. Ghana's New Christianity: Pentecostalism in a Globalising African Economy. Bloomington: Indiana University Press.

Goudzwaard, Bob 1989. Idols of Our Time. Downers Grove: InterVarsity Books.

Hall, Douglas John 2003. The Cross in our Context: Jesus and the Suffering World. Minneapolis: Fortress Press.

Hardenberg, Roland 2016. Beyond Economy and Religion: Resources and Socio-cosmic Fields in Odisha, India. Religion and Society 7:1, 83-96.

Heuser, Andreas, 2016. Charting African Prosperity Gospel Economies. Hervormde Teologiese Studies 72:4, 1-9.

Jolly, Marshall A. 2013. The Dark Side of the Mountain Anglican Theological Review 95:2, 325-333.

Kahl, Werner, 2015, "Jesus Became Poor so that We Might Become Rich"; A Critical Review of the use of Biblical Reference Texts among Prosperity Preachers in Ghana”. In Heuser, Andreas (ed.): Pastures of Plenty: Tracing Religio-scapes of Prosperity Gospel in Africa and Beyond, 101-115, Frankfurt: Peter Lang.

Kainulainen, Pauliina 2011. Geology vs. Theology? Uranium Prospecting and Theological Arguments in Northern Carelia. In Bedford-Strohm, Heinrich \& Deane-Drummond, Celia (eds): Religion and Ecology in the Public Sphere, 111-123. London: T\&T Clark. Kalu, Ogbu 2008. African Pentecostalism: An Introduction. Oxford: Oxford University Press. 
Knox, Peter, SJ 2015. Sustainable Mining in South Africa: A Concept in Search of a Theory. In Peppard, Christiana \& Vincini, Andrea (eds): Just Sustainability: Technology, Ecology, and Resource Extraction, 117-130. Maryknoll: Orbis Books.

Landman, Christina 2015. Youth on the Margins as Agents of Change? The Call for the Opening of Mines in Dullstroom-Emnotweni based on the Freedom Charter (1955). Studia Historiae Ecclesiasticae 41:1, 156-168.

Lauterbach, Karen 2016. Religious Entrepreneurs in Ghana. In Röschenthaler, U. \& Schulz, D. (eds.): Cultural entrepreneurship in Africa, 19-36. New York: Routledge.

Leatt, James 1982. Astride Two Worlds: Religion and Values among Black Migrant Mineworkers on South African Gold Mines. Journal of Theology for Southern Africa 38, 59-82

López, Elizabeth \& Ellison, Susan 2005. The Light of Justice: The Struggle Against Newmont Mining. Church \& Society, January/February 2005, 70-77.

Maloka, Tshidiso 1997. The Struggle for Sunday: All-male Christianity in the Gold Mine Compounds', in Elphick, R. \& Davenport, R. (eds.), Christianity in South Africa: A Political, Social and Cultural History, 242-253. Cape Town: David Philip.

McDaniel, Jay B. 2000. Living from the Center: Spirituality in an Age of Consumerism. St Louis: Chalice Press.

Nash, James A. 1991. Loving Nature: Ecological Integrity and Christian Responsibility. Nashville: Abingdon Press.

Rasmussen, Larry 2013. Earth Honoring Faith: Religious Ethics in a New Key. Oxford: Oxford University Press, 2013.

Rey, Jeanne 2015. Missing Prosperity: Economics of Blessings in Ghana and the Diaspora. In Heuser, Andreas (ed.): Pastures of Plenty: Tracing Religio-scapes of Prosperity Gospel in Africa and Beyond, 339-353, Frankfurt: Peter Lang.

Sekhejane, Moagi Cable Benty 2017. A Systematic-theological Exploration of Hydraulic Fracturing in South Africa. M.A. (Theology) thesis. University of Pretoria.

Thompson, Andrew R.H. Loving the Mountains: Cultivating a Compassion for Places. In Brotton, Melissa (ed): Ecotheology and Nonhuman Ethics in Society: A Community of Compassion, 101-116. Lanham: Lexington Books.

Tucker, A. Roger \& Van Tonder, Gerrit 2015. The Karoo Fracking Debate: A Christian Contribution to the World Communities of Faith. Science and Engineering Ethics 21:3, 631-653.

Wilkinson, Loren (ed) 1991. Earthkeeping in the '90s: Stewardship of Creation. Grand Rapids: WB Eerdmans.

Witt, Joseph Dylan. The Faith to Save Mountains: Religion and Resistance to Mountaintop Removal Coal Mining in Appalachia. D. Phil thesis. University of Florida.

World Council of Churches, Working Group on Climate Change. Climate Change. Geneva: WCC, 2005. 